\title{
Assessment of farmers' awareness, participation and sources of awareness of agroforestry practices in Taraba State, Nigeria
}

\author{
E. A. Karshie ${ }^{1 *}$, B. I. Dagba ${ }^{2}$ and S. A. Shomkegh ${ }^{2}$ \\ ${ }^{1}$ Department of Forestry, College of Agriculture, PMB 1025, Jalingo, Taraba State, Nigeria. \\ ${ }^{2}$ Department of Social and Environmental Forestry, College of Forestry and Fisheries, University of Agriculture, PMB \\ 2373, Makurdi, Nigeria.
}

Accepted 25 May, 2017

\begin{abstract}
The study assessed farmers' awareness of various agroforestry practices, participation in various agroforestry practices and sources of awareness of Agroforestry practices in Taraba State, Nigeria. A sample of 420 respondents drawn from 7 Local Government Areas (LGA) out of 16 LGA in all the agroecological zones in Taraba State was selected using multi-stage sampling techniques. The selected respondents were administered questionnaire on information related to awareness and participation level in agroforestry practices. Descriptive statistic of frequency count and percentage were used to explain the data while inferential statistics of Pearson product moment correlation was the analytical tool used to test the null hypothesis. The study reveals that extension agents (38.57\%), forestry department $(24.05 \%)$ and mass media (radio/television) (19.52\%) were the major farmers' sources of awareness. The study also revealed a significant relationship between farmers' awareness of agroforestry practices and their participation. It was recommended that more extension staff should be trained to enhance effective extension contact to farmers. Farmers should be educated and enlightened on the importance and benefits of agroforestry.
\end{abstract}

Keywords: Agroforestry, awareness, farmers, participation, Taraba State.

*Corresponding author. E-mail: drvictorajayi@gmail.com. Tel: +2348034012521.

\section{INTRODUCTION}

Population explosion, indiscriminate felling of trees for timber, over exploitation of firewood for fuel and charcoal, clearing of land for agricultural expansion and industrial development have exposed the land to rapid soil organic matter decomposition, accelerated water and wind erosion, flooding, land slide, desertification and threat of extinction of economic trees (Adedire, 2007). These hazards result in environmental degradation and make sustainable agriculture increasingly difficult. Agroforestry as a sustainable management system for land that increases total production, combines agricultural crops, tree crops and forest plants and/or animals simultaneously or sequentially and applies management practices that are compatible with the cultural patterns of the local population (Bene, 2009). The technique offers solution to land shortage, poverty, food security and environmental degradation.

Agroforestry is a way of instituting sustainable agricultural development in Nigeria was introduced a few years ago. This is to combat the various environmental problems observable with the purpose of assisting farmers to maintain the fertility of their soils, ensure diversification of crop, wood and timber species per unit area and to stabilize, improve and conserve farmers' environment. Participation of the farmers therefore becomes indispensable since it determines the success of the program. Olawoye cited in Akinbile et al. (2007) reported that the participatory approach to any 
intervention programme designed for the development of an area of interest has widely been accepted as a best way to ensure meaningful and sustainable benefits.

Access to agricultural information is one of the major prerequisites to improve agricultural productivity in Nigeria. Information and communication are essential ingredients needed for effective transfer of practices that are designed to boost agricultural production (Nair, 2008). For farmers to participate or benefit from such practices, they must first have access to reliable source of information and learn how to effectively utilize the information in their farming systems and practices. Sources of awareness are important in providing information for enabling the rural community to make informed decision regarding their farming activities, especially in the rural areas of developing countries (Lwoga, 2010). Information is the key for success in the operation and management process of the agricultural activities. To a large extent, sources of awareness serve as a veritable instrument for information dissemination in agriculture. Sources of awareness such as extension agents, forestry department, mass media (television/radio), fellow farmers and publications played vital role in creating awareness about agroforestry system practices among farmers. Sources of awareness help in spreading agroforestry practices related information to the farmers at a faster rate. Most of the inhabitants of Taraba State, Nigeria are subsistence farmers and they had been practicing traditional agroforestry systems for decades (Tukur and Adebayo, 2006). Over population and poverty have been identified as threat to the environment. The poor rural household depends on soil, trees and water for their livelihood in order to survive; they often destroy the natural resources that are of multiple benefits. The environment therefore becomes exposed to soil erosion, decreased biodiversity, which have biological, social and economic implications. In this regard, farmer participation in Agroforestry practices is therefore, essentially important for the desired benefits.

Mahmood and Sheikh (2005) stated that creation of awareness is the first step towards the participatory or adoption process. Awareness is one of the factors that may influence the level of farmers' participation in agroforestry system practices. Therefore, the study assessed if level of awareness have any influence on farmers level of participation in Agroforestry practices in the study area. The objectives of this study were to:

1. Identify the preferred and types of Agroforestry system practices in the study area.

2. Identify the respondents' level of awareness of Agroforestry practices in the study area.

3. Assess the respondents' level of participation in Agroforestry practices in the study area.

4. Identify the respondents' sources of awareness on agroforestry practices in the study area.
Study hypothesis:

$\mathrm{Ho}_{1}$ : There is no significant relationship between farmers' awareness and their participation in agroforestry practices.

$\mathrm{Ho}_{2}$ : There is no significant relationship between sources of awareness and farmers' participation in agroforestry practices

\section{MATERIALS AND METHODS}

The study was conducted in Taraba State, Nigeria. The State lies between Latitude $6.5^{\circ}$ and $8.5^{\circ}$ North of the Equator and longitude $9.0^{\circ}$ and $14.0^{\circ}$ East Meridian. The State is bounded to the North and Northeast by Gombe and Adamawa States, to the West and Southwest by Plateau and Benue States and to the South by the Republic of Cameroon as shown in Figure 1.

The choice of this area was premised on the fact that Agroforestry practice among the farmers has already been introduced by the Taraba State Agricultural Development Programme (TSADP). The state ADP has done this with the general objective of combating many of the environmental problems facing farmers in the state. There are three agro-ecological zones in study area namely; Zing, Wukari and Gembu agro-ecological zones.

Like most parts of northern Nigeria, Taraba State lies within the tropical sub-humid climate zone (Ayoade, 2009), with well-defined wet and dry seasons. The wet season lasts on the average, from April to October. Mean annual rainfall varies between $1058 \mathrm{~mm}$ in the north around Jalingo and Zing, to over $1300 \mathrm{~mm}$ in the South around Serti and Takum. The wettest Months are August and September. The dry season lasts from November to March. The driest Months are December and January with relative humidity dropping to about 15 percent. Mean annual temperature around Jalingo is about $28^{\circ} \mathrm{C}$ with maximum temperatures range between 15 and $23^{\circ} \mathrm{C}$. The Mambilla Plateau has climatic characteristics typical of a temperate climate. Temperatures are low throughout the year and the rainy season lasts from February to November with mean annual rainfall of over $1850 \mathrm{~mm}$ (Tukur and Adebayo, 2006).

A multistage sampling technique was used in this study. The three ADP Zone in consist of sixteen Local Governments Areas (LGAs). In stage one, three out of six LGAs (50\% representation) from Zing Zone and two out of five LGAs (40\% representation) from Wukari Zone and two out of five LGAs (40\% representation) from Gembu Zone were randomly selected. In the second stage, from the seven selected LGAs, three out of the ten circles $(30 \%$ representation) in each LGA were also randomly selected. This gave a total of 21 circles. In the third stage, twenty (20) farmers out of forty (40) farmers (50\% representation) per circle were randomly selected making the sample size of the study to constitute 420 farmers.

The instrument used in the study was Farmer's Participation in Agroforestry Practices Questionnaire (FPAPQ) schedule. This questionnaire was utilized to obtain primary data and secondary data from Journals publications and internet materials. The primary data was information generated on farmer's awareness of agroforestry practices, sources of awareness of agroforestry practices and level of their participation in agroforestry practices and suggestions of possible ways of improving the situation. The instrument used for data collection was validated for content appropriateness and it was also subjected to pre-test which yielded a reliability of 0.76 using Pearson Moment Correlation Coefficient. The interview schedules were through trained enumerators.

Descriptive statistic of frequency count and percentage were used to explain the data while inferential statistics of Pearson 


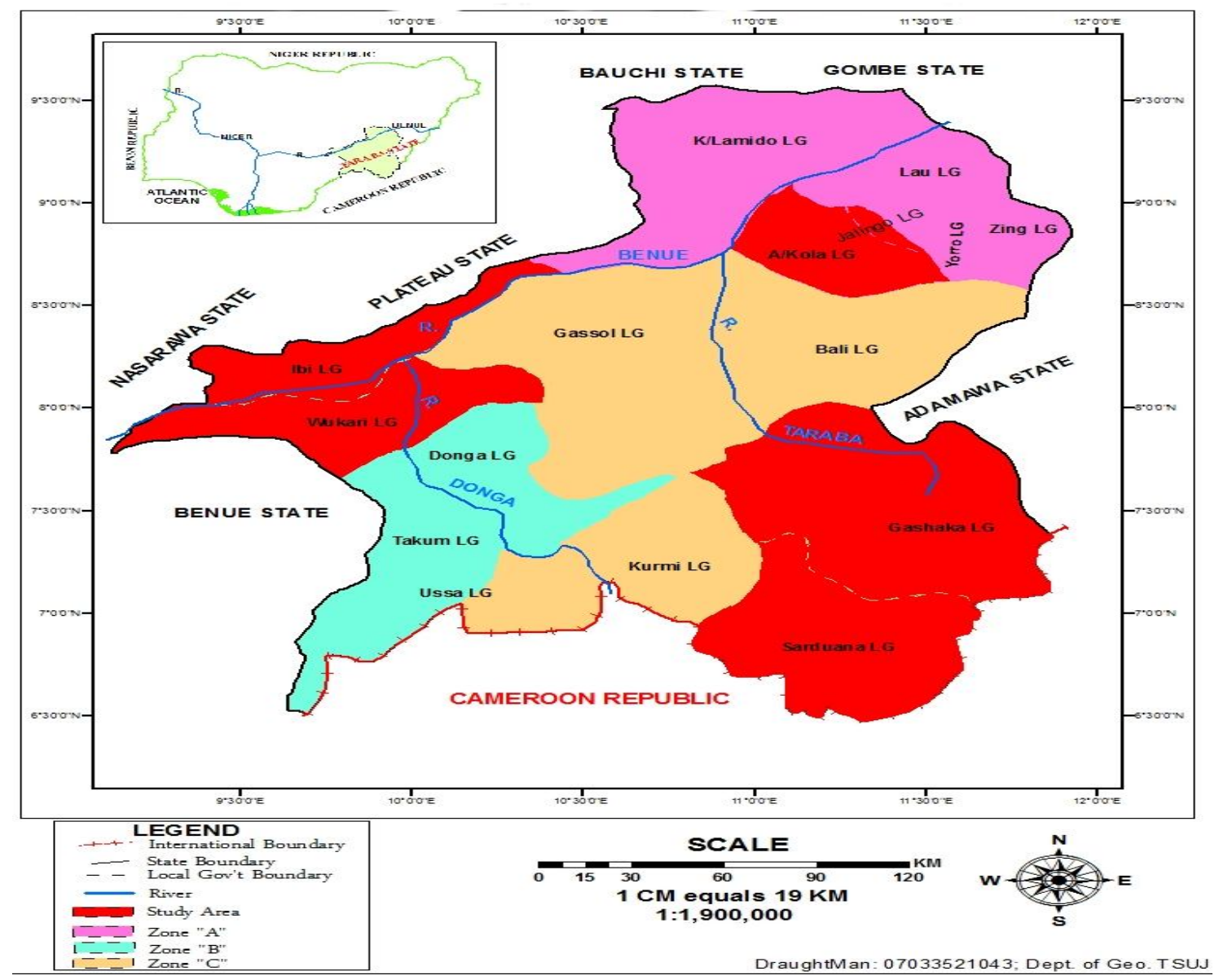

Figure 1. Map showing the study area.

Product Moment Correlation was employed to test the hypotheses.

\section{RESULTS AND DISCUSSION}

The result in Table 1 showed that agrosilviculture (Interplanting of woody plants and agricultural crops), silvopastoral (Integrated trees/pasture), agropastoral (Mixed intercropping), home garden, and shelterbelt (Hedgrow cropping) ranked the first five most preferred agroforestry practices in Taraba State while Sericulture (Silkworm farming) has the least ranking in terms of preferred practice.

The result in Table 2 indicated that $98.8 \%$ of the farmers were aware of agrosilviculture (Inter-planting of woody plants and agricultural crops) and $93.2 \%$ of the farmers do participate in agrosilviculture at different levels, $88.6 \%$ of the farmers were aware of agropastoral (Mixed intercropping/livestock) and $72.3 \%$ of the farmers do participate in agropastoral at different levels and $81.2 \%$ of the farmers were aware of silvipastoral (Trees and livestock) and $79.3 \%$ of the farmers do participate in silvipastoral at different levels while sericulture (silkworm farming) has the least awareness of $24.6 \%$ and least level of participation of $6.0 \%$. By implication, this implies that farmers' awareness, determined their participation in Agroforestry practice.

The result in Table 3 indicated that $38.57 \%$ of the farmers became aware of agroforestry practice(s) through ADP (extension agents). While 24.05, 19.52, and $15.72 \%$ respectively sourced their awareness through forestry department, mass media (radio/television) and through fellow farmers respectively while $2.14 \%$ of the farmers became aware of the practice(s) through publications. This probably justifies the effort of ADP in creating agroforestry system practices awareness in Taraba State. The result in Table 4 implies that the awareness of agroforestry practices significantly predicted farmers' participation. That is, awareness had a strong positive correlation with farmers' participation in Agroforestry practices. That is, $61.00 \%\left(0.781^{2}\right)$ of the variation in farmers' participation is explained by awareness. This finding agrees with Ahmad, et al (2007) who reported that there was a significant statistical relationship between awareness and participation in afforestation. Table 5 revealed that $r=0.670, P=0.000$. 
Table 1. Preferred agroforestry system practices in Taraba State, Nigeria.

\begin{tabular}{lllc}
\hline Agroforestry system & Key components & Common examples & Preferred practices \\
\hline Agrosilviculture & Wood perennials and agricultural crops & Alley farming and wind break & $1 \mathrm{st}$ \\
Silvipastoral & Trees and livestock & Integrated trees-pasture & 2 nd \\
Agro pastoral & Crops and livestock & Alley cropping & 3 rd \\
Aquasilviculture & Aquatic organisms and tree production & Tree, snail and fish farming & 8 th \\
Sericulture & Silkworm production & Silkworm farming & 10 th \\
Apiculture & Bee-keeping & Honey production & 9 th \\
Community Forestry & Village woodlots & Roads sides or canals planting of trees & 7 th \\
Taungya Farming & Crops and trees & Food crops and tree production & 6 th \\
Shelterbelt & Food crops and tree planted as shelter & Hedgrow cropping & 5 th \\
Home Garden & Trees, shrubs, and livestock & Homegarden & 4 th \\
\hline
\end{tabular}

Table 2. Percentage of farmers' awareness participation in agroforestry practices in Taraba State, Nigeria.

\begin{tabular}{|c|c|c|c|c|c|c|c|c|}
\hline \multirow{2}{*}{$\begin{array}{l}\text { Agroforestry system } \\
\text { practices }\end{array}$} & \multicolumn{2}{|c|}{ Awareness $(n=420)$} & \multicolumn{6}{|c|}{ Level of participation $(n=420)$} \\
\hline & No response & Yes & No & No response & Never & Rarely & Often & Always \\
\hline Agrosilviculture & 0 & 98.8 & 1.2 & 6.8 & 0.0 & 2.2 & 11.6 & 79.4 \\
\hline Silvipastoral & 12.3 & 81.2 & 6.5 & 14.9 & 5.8 & 6.6 & 13.5 & 59.2 \\
\hline Agropastoral & 9.4 & 88.6 & 2.0 & 21.5 & 6.2 & 11.6 & 22.4 & 38.3 \\
\hline Aquasilviculture & 18.2 & 80.2 & 1.6 & 30.4 & 32.6 & 12.4 & 20.2 & 4.4 \\
\hline Sericulture & 22.4 & 24.6 & 53.0 & 25.6 & 68.4 & 3.6 & 2.4 & 0.0 \\
\hline Apiculture & 19.2 & 25.4 & 55.4 & 25.2 & 66.2 & 5.0 & 2.4 & 1.2 \\
\hline Community forestry & 15.2 & 65.3 & 19.5 & 20.0 & 33.8 & 14.8 & 18.6 & 12.8 \\
\hline Taungya farming & 14.6 & 83.6 & 1.8 & 24.2 & 23.2 & 12.4 & 16.8 & 23.4 \\
\hline Shelterbelt & 23.7 & 64.3 & 12.0 & 30.7 & 21.8 & 9.7 & 12.3 & 25.5 \\
\hline Home garden & 6.2 & 92.0 & 1.8 & 27.0 & 2.0 & 10.4 & 24.4 & 36.2 \\
\hline
\end{tabular}

Table 3. Frequency count and percentage of farmers' sources of awareness of agroforestry practices in Taraba State, Nigeria.

\begin{tabular}{lcccccc}
\hline \multirow{2}{*}{ Source of awareness } & Zing zone & Wukari zone & Gembu zone & $\begin{array}{c}\text { Total freq. } \\
\text { ( } \mathbf{n = 4 2 0})\end{array}$ & Total percentage (\%) \\
\cline { 2 - 5 } & Freq. & Freq. & Freq. & 162 & 38.57 \\
\hline ADP (Extension agent) & 73 & 47 & 42 & 101 & 24.05 \\
Through Forestry Department & 43 & 30 & 28 & 82 & 19.52 \\
Mass media (radio/television) & 31 & 24 & 27 & 66 & 15.72 \\
Through Follow Farmers & 26 & 18 & 22 & 9 & 2.14 \\
Through Publications & 7 & 1 & 1 & & \\
\hline
\end{tabular}

Table 4. Relationship between farmers' awareness and participation in agroforestry practices in Taraba State, Nigeria.

\begin{tabular}{lcccc}
\hline Variables & N & r & P Value & Decision \\
\hline Awareness and Farmers' Participation & 420 & $0.781^{*}$ & 0.000 & $\mathrm{~S}$ \\
\hline
\end{tabular}

${ }^{*}$ Significant at $\mathrm{P}<0.05 ; \mathrm{S}=$ Significant, NS = Not Significant.

Table 5. Relationship between sources of awareness and farmers' participation in agroforestry practices in Taraba State, Nigeria.

\begin{tabular}{lcccc}
\hline Variables & $\mathbf{N}$ & $\mathbf{r}$ & P Value & Decision \\
\hline Sources of Awareness and farmers' participation & 420 & $0.670^{\star}$ & 0.000 & S \\
\hline
\end{tabular}

*Significant at $\mathrm{P}<0.05 ; \mathrm{S}=$ Significant, NS = Not Significant. 
Since, $p<\alpha=0.05$, this implies, the null hypothesis that says, there is no significant relationship between source of awareness and farmers' participation in agroforestry practice is rejected. This implies that, source of awareness had a strong positive correlation with farmer level of participation in Agroforestry practices. That is, $44.89 \%\left(0.670^{2}\right)$ of the variation in farmers' participation is explained by sources of awareness. This finding agrees with Ayuba (2013) who reported that there was a significant statistical relationship between sources of awareness and participation in afforestation.

\section{CONCLUSION}

It is evident from the findings of this study that ADP (extension agents), forestry department and mass media (radio/television) are the major farmers' sources of awareness and farmers' awareness significantly influenced or predicted their participation in agroforestry practices in Taraba State, Nigeria.

\section{RECOMMENDATIONS}

1. Taraba State Agricultural Development Programme (ADP) and Ministry of Agriculture should train more extension staff to enhance effective extension contact to farmers.

2. Farmers should be educated and enlightened about the importance and benefits of agroforestry. This could be achieved through proper extension programmes, media communication, among others.

3. Formulation of radio listening groups among the farmers should be encouraged to enhance the farmers awareness of agroforestry that consequently result in improvement of participation in agroforestry practices in the study area.

\section{REFERENCES}

Adedire AA, 2007. Agroforestry systems in Nigeria: Review of concepts and practices. J Res Forest Wildlife Environ, 1(1): 18-24.

Ahmad M, Akram M, Rauf R, Khan IA, Pervez U, 2007. Interaction of extension workers with farmers and role of radio and television as sources of information in technology transfer: A case study of four villages of district Peshawar and Charsadda. Sarhad J Agric, 23 (2): 515-518.

Akinbile LA, Salimonu KK, Yekinni OT, 2007. Farmers' participation in agroforestry practices in Ondo State, Nigeria. Res J Appl Sci, 2(3): 229-232.

Ayoade S, 2009. Influence of relief on rainfall distribution in Upper Benue River Basin Development Authority area, Nigeria. Nat Geo J, 44(1): 34-38.

Bene BS, 2009. Evaluation of agroforestry technology practices in Kebbi State. Int J Environ Sci, 3(3): 23-28.

Lwoga ET, 2010. Bridging the agricultural knowledge and information divide: The case of selected telecenter and rural radio in Tanzania. EJISDC, 43(1): 1-14.
Mahmood MA, Sheikh AD, 2005. Crop yields from new technologies. Retrieved on $12^{\text {th }}$ Febuary, 2017 from http://www.newpractice/9j Isourceofinformation.

Nair PKR, 2008. An Introduction to Agroforestry. Netherlands: Kluwer Academic Publishers.

Tukur AL, Adebayo AA, 2006. Taraba on Map. Yola: Parachete Publishers.
Citation: Karshie EA, Dagba BI, Shomkegh SA, 2017. Assessment of farmers' awareness, participation and sources of awareness of agroforestry practices in Taraba State, Nigeria. Net J Agric Sci, 5(2): 66-70. 